\title{
ICELANDIC WAY OF ECONOMIC DEVELOPMENT AFTER THE CRISIS
}

\author{
Ewa Szymanik ${ }^{129}$
}

https://doi.org/10.31410/itema.2018.322

\begin{abstract}
The article presents the consequences of the crisis for Iceland, its current situation and conclusions for the future: the ability to make use of competitive advantages, the advantages and threats of rapid development of tourism and construction industry, the location of a large number of cryptocurrency "mines". The aim is to show the effects of applying unconventional solutions. The descriptive analysis was used as the research method.
\end{abstract}

Keywords: Iceland, economic development, tourism, cryptocurrency, opportunities and threats

\section{INTRODUCTION}

$\mathrm{I}$ $\mathrm{n}$ recent years Iceland was the centre of attention due to the speed with which it overcame the crisis. The unconventional solutions, pace and depth of the changes made Iceland a model country to others. However, it was also criticised. Therefore, it is worth taking a closer look at its current situation and analyzing the development way chosen by this country.

The aim of the article is to present the current situation of Iceland, the sources of its successful overcoming of the crisis and analysis of opportunities for further economic development, as well as to draw attention to the possible threats and potential sources of further breakdowns.

\section{GENERAL CHARACTERISTICS OF THE ICELANDIC ECONOMY}

According to [17], the financial crisis are rapid changes in financial markets, related to the lack of liquidity of business entities, insolvency and state intervention in economic processes. Incidents in Iceland are a perfect illustration of this definition. The reason for the sudden collapse were the wrong moves of the representatives of major banks involving investment of foreign clients' money in US mortgage bonds. At the peak, assets of Icelandic banks exceeded GDP tenfold.

The Icelandic economy was developing quite rapidly before the crisis. It attracted foreign direct investment, which reached 33\% of GDP in 2007. Despite the collapse in the following year, the inflow (albeit much smaller and shaping differently) took place until 2016, when for the first time the outflow of foreign investments reaching almost $6 \%$ of GDP was observed [12].

The economy of Iceland started to develop very quickly after a sharp downturn in 2008 . According to [26] Iceland was ranked 20th in the world and 11th in Europe among the most competitive economies. Table 1 shows current economic situation of Iceland.

\footnotetext{
${ }^{129}$ Cracow University of Economics, Rakowicka 27, 31-510 Kraków, Poland
} 
Table 1. Economic situation of Iceland (selected years 2008-2017)

\begin{tabular}{|c|c|c|c|c|c|c|c|}
\hline & 2008 & 2010 & 2013 & 2014 & 2015 & 2016 & 2017 \\
\hline GDP (bln ISK) & 1551 & 1620 & 1891 & 2006 & 2214 & 2453 & 2555 \\
\hline GDP increase (\%) & 1.5 & -3.6 & 4.4 & 1.9 & 4.2 & 7.5 & 3.6 \\
\hline Inflation $(\%)$ & 12.8 & 7.5 & 6 & 4.1 & 2 & 1.7 & 1.8 \\
\hline Unemployment (\%) & 3 & 7.6 & 5.4 & 4.9 & 3.4 & 3 & 2.7 \\
\hline $\begin{array}{l}\text { The average employment in the } \\
\text { touristic sector (thousands) }\end{array}$ & 9.97 & 11.23 & 16.07 & 17.82 & 20.4 & 24.28 & 27.22 \\
\hline $\begin{array}{l}\text { The average employment in the } \\
\text { touristic sector ( } \% \text { of employed) }\end{array}$ & 5.6 & 6.7 & 9.2 & 10 & 12.1 & 33.8 & 37.5 \\
\hline $\begin{array}{l}\text { The employment in fishery and } \\
\text { agriculture }(\%) \text { : }\end{array}$ & 5 & 6 & 4.4 & 4.5 & 4.2 & 3.9 & 3.5 \\
\hline Industry & 22 & 18 & 18.5 & 18.4 & 17.8 & 17.8 & 17.7 \\
\hline Services & 73 & 76 & 76.7 & 76.9 & 77.7 & 78.3 & 78.6 \\
\hline Budget deficit/surplus (bln ISK) & -202 & -158 & -34.8 & -1.5 & - & 308.4 & 38.7 \\
\hline Budget deficit (\% GDP) & $\begin{array}{l}- \\
13.1\end{array}$ & -9.8 & -1.9 & -0.1 & -0.8 & 12.6 & 1.5 \\
\hline Current balance (bln ISK) & -348 & -95.7 & 127 & 92.4 & 148 & & \\
\hline Trade balance (bln ISK) & -6.7 & 120.2 & 40.2 & 4.3 & - & 158.8 & 105.1 \\
\hline $\begin{array}{l}\text { Tourism income share in GDP } \\
(\%)\end{array}$ & 4.6 & 3.5 & 4.9 & 5.6 & 6.7 & 8.4 & - \\
\hline
\end{tabular}

Source: own calculations on the basis of http://www.statice.is/, 02.05.2018

The growth rate, which has been maintained since 2011, is mainly the result of high government expenditure and tourism development, though not only. The unemployment rate - always low - is until declining. Iceland again became a country with net inflow of immigrants [13], mostly employed in the tourism sector.

According to [10], Iceland is ranked 11th in the global ranking of economic freedom and 5th in Europe. It has one of the best systems of protection of property rights, low corruption and high economic freedom. In 2017 public debt reached 53.2\% of GDP.

The country has been developing quickly after the deep recession, which reached the bottom in 2011. These positive changes are, among others, the result of a good use of loans obtained from IMF, Nordic countries, Russia and Poland ${ }^{130}$. Iceland repaid its loans before the due date - until autumn 2015 [7].In the same year Iceland was also the first country to exceed the pre-crisis level of economic development.

\section{ECONOMIC TRANSFORMATION}

The economy of Iceland changed after the crisis. Firstly, overheating of the economy stemmed from overinvestment in the energy sector developed mainly for the purposes of the aluminium industry. There was a situation in which the production of aluminium was not important, construction related to it really mattered, constituting main source of development. Secondly, previous reforms enabled a creation of financial bubbles and a threefold increase in prices on the real estate market [23], which was connected with an easy access to loans. The collapse of

\footnotetext{
${ }^{130}$ Poland lent 214 million dollars to Iceland [19].
} 
the largest banks prevented further rapid growth - their debts exceeded almost tenfold the value of GDP.

The IMF estimates that the costs of the crisis amounted to $40 \%$ of GDP. Net costs of fiscal support and restructuring of domestic banks amounted to $19.2 \%$ of GDP[3].

These problems came as a shock to Icelanders. They often did not have any savings, so they could not cope after losing their sources of income. Some of them emigrated looking for work abroad. Apart from a rise in unemployment, tax rate also increased [1], while salaries remained unchanged. A necessity to make savings appeared.

The authorities took a radical action. Banks were allowed to collapse, no debts were repaid to foreign creditors. The devaluation of the Icelandic króna turned out to be a success (by 70\%) what triggered inflation, which in 2009 amounted to $18 \%$ per annum [15], and salary increase was frozen. The focus was shifted from the banking sector to traditional industries (fishing and tourism), in the development of which helped a decline in value of the currency. Depositors were assured to receive their bank deposits, national entities were granted reliefs in repayment of existing loans, public expenditure was cut.

Iceland had some advantages over the countries of the Union when it started to fight the crisis. Firstly, it had relatively low foreign debt (28.5\% of GDP in 2008) and achieved budget surpluses each year. Secondly, it had floating exchange rate of the króna, which caused a large devaluation (30-50\%), but at the same time it allowed to maintain important export markets [2] and to increase export revenues [16].

The devaluation of the currency helped to keep real salaries at almost the same level, which saved households expenditure from drastic decrease, even though the króna was worth less. Thanks to this the economy started to develop.

Moreover, conclusions were drawn regarding causes and ways of avoiding similar economy breakdowns in the future. A report was created indicating that the main reason of the problems was an excessive creation of money by commercial banks. Findings of the report show how to change it without disrupting the functioning of the entire banking system. Sovereign money system should serve this purpose, where the entire possibility of money creation would belong exclusively to a central bank [21]. The Icelandic government analyzed the report, but did not decide to implement its conclusions. This does not mean, however, that financial issues were set aside. Strong exchange rate fluctuations raise concerns about the overheating of the economy. Various options are considered, such as linking the exchange rate of the króna with another currency (euro) or introducing additional tools, alongside the interest rate, allowing to control the exchange rate [27].

Despite not joining the EU, Iceland uses conveniences of European integration in a selective way - it belongs to the EEA and Schengen area, which promotes development (it adopted 18\% of the Union regulations). The country has remained at its own currency, which makes it possible to control the banking system to avoid collapse in the future. The procedure for abolishing capital control was completed in March 2017 (only a part of the provisions regarding, among others, the so-called carry trade was left).

The collapse of the króna also contributed to an improvement of competitiveness of the economy. A great inflow of tourists took place after 2010, for whom holidays on the island 
became exotic - and cheaper. Because of the crisis Iceland appeared in global media attracting public attention.

Although the economic collapse initially caused a turn towards the development of traditional sectors (fishing, tourism, aluminium production), there was, however, a dynamic shift towards the renewable energy and the development of information technology [22].

What are the threats? According to the report [4] from 2017, the weakness of the country is government instability, still disadvantageous structure of the economy, basing export mainly on the sale of fish and aluminium, susceptibility of economy to overheating and strong financial shocks, as well as still high (despite steady decline) level of foreign debt (reaching 95\% of GDP). The exchange rate and risk of inflation are monitored but the threat of the collapse did not disappear, despite low energy prices and the appreciation of the króna. A slight increase in nominal salary supported a growth of inflation expectations. In addition, sudden and large capital flows may lead to short-term disequilibrium and exchange rate volatility putting pressure on the balance of payments.

Other threats result from still a large share of traditional sectors in the economy. Fishing generates about $12 \%$ of GDP but it is subject to many limitations, similar to tourism. The lack of ability to provide cheap meals for mass tourism causes a rise in prices, which combined with high prices for accommodation, will limit the inflow of visitors. The analysis carried out by Landsbanki shows that the country has been strongly dependent on this branch of the economy for several years. In 2016, revenues from tourist services reached 39\% of the total export value, and are estimated to reach $42 \%$ in 2017 . Research conducted among 39 countries shows that Iceland is the only one in which there is a positive correlation between currency appreciation and influx of tourists, which allows the conclusion that tourism development is not so strongly linked to changes in the exchange rate, as can be seen in the example of other countries [5]. It is possible, however, that Iceland has already reached its peak regarding the interest of tourists and the trend for visiting it is slowly disappearing, which is caused by high costs of accommodation, although the forecasts indicate that the number of tourists may grow, even though slower, until 2019.

The country is heavily dependent on oil. Moreover, the vast majority of products is imported. Low oil prices translated into transport costs, so the economy developed quickly, which accelerated overcoming the crisis. The situation in the future, however, might change.

Another threat has a potential character, but is similar to the one that triggered the crisis in 2007. This is the cryptocurrency market.

Iceland is a country with high "mining" of cryptocurrency in the "mines". These are computer centres connected to the global Bitcoin network, where computers solve mathematical problems in the process of checking the correctness of transactions between cryptocurrency users. These data centres consume electricity on a massive scale (current consumption by households is approx. $700 \mathrm{GWh}$ per year, while "mines" are expected to consume about $840 \mathrm{GWh}$ ) [25]. Production capabilities of the country are limited. Moreover, there is a concern that there are almost no benefits of locating the "mines" for the country because employment in them is marginal, similar to investment capital. They also do not generate tax revenues, hence there was a postulate in the parliament regarding taxation of the "cryptocurrency mines". There can be no total abandonment of the opportunity (many companies would like to make this kind of investment), as this market is developing quickly and although it is burdened with a huge risk, 
it gives Iceland further development opportunities (the installation of one of the first bitcoin ATM in Europe serves as an example [24]).

Iceland also wants to tighten the tax system. It was proposed to withdraw the banknotes with the highest denominations (10 and 5 thousand krónur) from circulation and to extend the scope of electronic payments as part of the fight against tax evasion. It is estimated that $3-7 \%$ of GDP has been lost in the last 30 years and the budget loses about $10 \%$ of potential revenues annually since many people offering tourist services have been operating within the "grey economy". Moreover, there are suspicions that the country was used as a place of "money laundering" by terrorists [29].

Despite these threats, Iceland's financial situation is good and stable enough so that the government decided to reduce the corporate income tax rate and introduce a single rate of personal income tax. The total rate is $36 \%$, which means a large decrease (from $47 \%$ ) [18]. This means that the financial capabilities of the entities will increase and will be an additional incentive for development, and thus for an increase in budget revenues.

\section{CONCLUSIONS}

It is possible to draw some conclusions on the basis of the analysis of the available data.

The implementation, speed and high efficiency of reforms resulted from the specific features of the discussed economy. Iceland is a small country, its residents are disciplined and have a high civil awareness. Due to these, among other things, the country managed to overcome the collapse quickly.

One of the important factors, which contributed to improvement of the situation, is a significant development of tourism, including a very unusual one - following the movies produced on the island. This means that another sector, which might become a driving force of the economy is widely understood artistic creation (in 2012 more than 7 thousand companies were registered in this sector) [15].

Iceland used its unusual competitive advantages: activity of volcanoes, geothermal energy, hydropower stations (aluminum production, server rooms). A global interest in this small country has increased, and consequently - the inflow of financial resources. Since traditional culture is based on education in the humanities, including a common knowledge of English, the country was not surprised by the wave of globalization and is able to take advantage of the sudden increase in interest.

Icelanders made a good use of the inflow of tourists - new accommodations, catering trade development, unusual museums (e.g. Museum of Rock'n'Roll). A developed network of bus connections enables to explore many attractive and difficult to reach places by the use of public transport, operating during summer, with long stops to sightsee the surroundings. Also a widely developed system of campsites and mountain shelters, mountain rescue, tourist information functions smoothly. ${ }^{131}$

\footnotetext{
${ }^{131}$ Own research
} 
However, the disadvantages have also appeared. Life in Iceland is expensive - ISK 1000 is the basic "unit of account", which means that the cost of accommodation is very high for an average tourist, which is also due to the high increase in accommodation prices.

The inflow of tourists is intense. In 2016 it was 1767726 people, and in 2017 - 2195271, which means an increase of $24.2 \%$ compared to the previous year [27]. This is over six times more than the entire population of the country. This phenomenon is another source of - on the one hand - opportunities, on the other - development threats. Real estate prices are increasing and there are concerns that taking loans for new apartments, rented to tourists, will lead to a growth of another speculative bubble, this time generated by the real estate market. The risk is that growing debt makes entities more susceptible to economic disruptions [6]. Another threat is a burden for the natural environment by such a high number of visitors. Introduction of various limitations is being considered to restrict the freedom of movement of tourists, especially individual ones, which constitute the majority (e.g. by strictly limiting the number of cars to rent or the number of daily visits to national parks). $11 \%$ tax on many tourist services was introduced from 01.01.2018 [9]. Also introduction of new types of taxes for this industry is taken into account (additional fees for carriers and hotels, which would mean a further increase in prices) [14]. Increasing distribution of traffic for the whole year is hopeful - slightly less tourists decide to come in the summer, preferring to admire the Northern Lights, which means less burden for the environment, as these usually short journeys to specific places.

During the crisis educated Icelanders decided to emigrate temporarily or started their own business [8], what might become an additional driving force of the economy. There is no doubt, however, that a bigger diversification of the economic base is needed.

Strengthening of the króna is also a factor with a double impact on economic development. On the one hand, it enables accumulation of foreign exchange reserves, on the other - the influx of tourists will not grow forever.

All these determinants: strong wage growth caused by rapid economic development, strengthening of the króna, low inflation, increase in real estate prices and low interest rates are associated with the risk of overheating of the economy. At the same time, however, a good fiscal situation and a positive net international investment position are enabling factors [19], similar to the use of an unconventional solution, which was rescuing own economy at the expense of the refusal of repayment of debts to foreign countries. It turned out, however, that this type of action can be effective - the country is developing very fast, which was also influenced by the fact that Iceland has its own currency - it allowed the government to use an additional tool, i.e. control of the exchange rate. It is possible to draw an important conclusion - one should not hurry with monetary integration.

Undoubtedly, Iceland's development is unique and it is worth observing whether the way chosen by this country will turn out to be adequate in the long turn.

\section{REFERENCES}

[1] Budyta - Budzyńska, M., (2018) Islandzki kryzys finansowy a strategie adaptacyjne Polaków na Islandii, p.115, http://www.migracje.civitas.edu.pl/migracje/index.php/pl/islandzki-kryzys-finansowy-astrategie-adaptacyjne-polakow-na-islandii, 2. May 2018

[2] Cukiernik, T., (2012) Islandia - jak wyjść z kryzysu?, „Najwyższy Czas”, nr 38 
[3] Davíðsdóttir's, S. Icelog, (2015) Iceland's recovery: myths and reality (or sound basics, decent policies, luck and no miracle), 23. September, http://uti.is/2015/09/icelandsrecovery-sound-basics-decent-policies-luck-and-no-miracle/, 2 May 2018

[4] Euler Hermes, (2017), http://www.eulerhermes.com/economic-research/countryreports/Pages/Iceland.aspx, 5 May 2018

[5] Growth seeking balance - Economic analysis of tourism in Iceland, (2017) Landsbanki, $29 \quad$ September, https://corporate.landsbankinn.com/media/news-andnotifications/2017/09/29/Growth-seeking-balance-Economic-analysis-of-tourism-inIceland/?p=6, 6 May 2018

[6] Guðmundsson, M., (2017) Financial stability, Islands Seðlabanki, No.1, p. 3 https://www.cb.is/library/Skraarsafn---EN/Financial-Stability-Report/2017-

1/FS_2017_1_Heildarskjal_.pdf, 2 May 2018

[7] Guðmundsson, M., (2018) Iceland's recovery - facts, myths, and the lesson learned, Islands Seðlabanki, 28 January, http://www.sedlabanki.is/library/Skraarsafn/Raedur-erindi-og-

greinar/LOKA $\% 20 \mathrm{MG} \% 20$ Speech $\% 20 \mathrm{in} \% 20$ London $\% 20$ OMFIF $\% 20$ lecture $\% 20 \mathrm{Jan} \% 2$ 02016x\%20M.pdf, 2 May 2018

[8] How did Iceland clean up its banks?, (2016) 10 February, http://www.bbc.com/news/business-35485876, 20 April 2018

[9] http://guest-house-iceland.com/wp/index.php/how-to-book/, 5 May 2018

[10] http://www.heritage.org/index/country/iceland, 5 May2018

[11] http://www.statice.is/, 5 May 2018

[12] https://tradingeconomics.com/iceland/foreign-direct-investment-net-inflows-percent-ofgdp-wb-data.html, 10 May 2018

[13] Icelandic economic situation overview, (2015) Ministry of Finance and Economic Affairs, March, pp. 3 - 14

[14] Islandia obawia się napływu turystów. Rzad rozważa podniesienie podatków, (2017) „Forbes”, 17 March, https://www.forbes.pl/wiadomosci/naplyw-turystow-do-islandii-iplany-podniesienia-podatkow/cbrmbry, 23 March 2018

[15] Islandzki cud gospodarczy. Nie ratowali banków i interesów wierzycieli, (2012) 9 January, http://tvn24bis.pl/wiadomosci-gospodarcze,71/islandzki-cud-gospodarczy-nie-ratowalibankow-i-interesow-wierzycieli,281499.html, 25 April 2018

[16] Matsangou, E., Failing banks, winning economy: the truth about Iceland's recovery, (2015), "World Finance", 15 September, http://www.worldfinance.com/infrastructureinvestment/government-policy/failing-banks-winning-economy-the-truth-about-icelandsrecovery, 8 April 2018

[17] Natura i różnorodność przebiegu kryzysu światowego, Miklaszewski, S., (ed.), (2011), Difin, Warszawa, p.85

[18] Mitchell, D., (2018) Mitchell: Islandia kuruje się z przeziębienia dzięki rewolucji podatku liniowego, $\quad 22$ January, http://www.pafere.org/2018/01/22/bibliotekawolnorynkowa/daniel-j-mitchell/mitchell-islandia-kuruje-sie-z-przeziebienia-dziekirewolucji-podatku-liniowego, 5 May 2018

[19] Pielach, M., (2017) Islandia wychodzi z kryzysu tak szybko, że może wpaść w kolejny”, „Obserwator Finansowy.pl”, 2 August, https://www.obserwatorfinansowy.pl/tematyka/bankowosc/islandia-wychodzi-z-krysysutak-szybko-ze-moze-wpasc-w-kolejny, 2 May 2018

[20] Polska udzieli Islandii pomocy finansowej w wysokości 200 mln dolarów, (2008),Gazeta Wyborcza" 7 November 
[21] Reforma monetarna. Lepszy system monetarny dla Islandii. Raport sporzadzony przez Frosti Sigurjónssona na zlecenie premiera Islandii,(2015) Fundacja Jesteśmy Zmianą, Warszawa

[22] Shipman, A., (2016) Diamond geysers: rule - breaking Iceland completes its miracle economic escape, "The Conversation", 25 May, https://theconversation.com/diamondgeysers-rule-breaking-iceland-completes-its-miracle-economic-escape-59774, 20 April 2018

[23] Sutowski, M., (2010) Ostateczny krach systemu korporacji, w: Islandia. Przewodnik nieturystyczny, Wydawnictwo Krytyki Politycznej, Warszawa, p.139

[24] Szewczuk, M.,(2018) Islandia ma swój pierwszy bankomat bitcoinów,’Icelandnews”, 25 February, $\quad$ http://icelandnews.is/wiadomości/z-kraju/islandia-ma-swoj-pierwszybankomat-bitcoinow, 19 April 2018

[25] Szewczuk, M., (2018) Kopalnie kryptowalut w Islandii zużywaja więcej energii niż wszystkie gospodarstwa domowe,"Icelandnews", $16 \quad$ February, http://icelandnews.is/wiadomości/z-kraju/kopalnie-kryptowalut-w-islandii-zuzywajawiecej-energii-niz-wszystkie-gospodarstwa-domowe, 19 March 2018

[26] The World Competitiveness Yearbook 2017, (2017), IMD, https://www.imd.org/wcc/world-competitiveness-center-rankings/competitiveness-2017rankings-results/ , 2 May 2018

[27] Tuszyński, M., (2018), Islandia zmieni system walutowy?, „Parkiet”, 30 January, http://www.parkiet.com/Gospodarka---Swiat/301309852-Islandia-zmieni-systemwalutowy.html, 5 May 2018

[28] 2,2 million foreign passengers 2017, Icelandic Tourist Board, https://www.ferdamalastofa.is/en/moya/news/22-million-foreign-passengers-2017, 5 May 2018

[29] W ramach walki z szara strefa Islandia stawia na rozliczenia bezgotówkowe, (2017), „Obserwator $\quad$ Finansowy.pl”, 7 September, https://www.obserwatorfinansowy.pl/tematyka/rynki-finansowe/w-ramach-walki-zszara-strefa-islandia-stawia-na-rozliczenia-bezgotowkowe, 23 March 2018 